\title{
A reformed-theological engagement with the resurrection of Jesus Christ
}

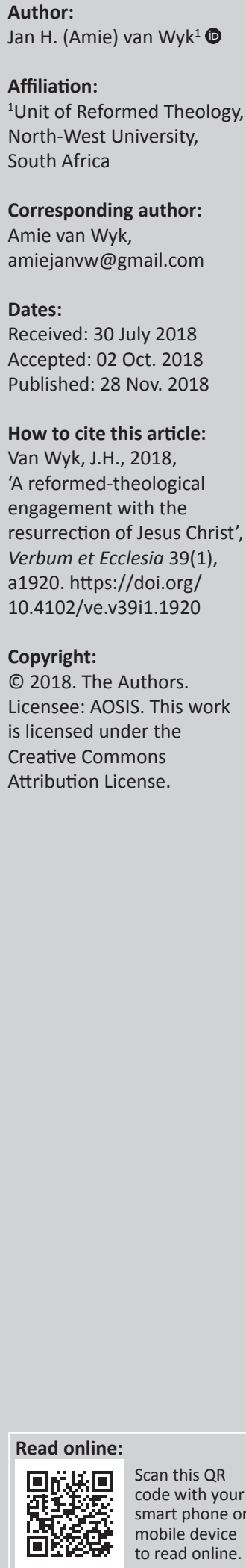

\begin{abstract}
In this article, the author investigates the manifold interpretations that were given to the resurrection of Jesus Christ. This is a topic which has caused many disturbances in the Christian church right from the very beginning and is therefore not a modern phenomenon, although a more critical approach has gained momentum since the Aufklärung of the 18th century with its rationalism and positivism. The resurrection is not an everyday experience and cannot be verified in any way. The author investigates different approaches to this topic, namely the classic realistic interpretation (pneumatic realism), metaphoric realism, demythologisation and elevation. Special attention is given to the view of the eminent South African systematic theologian Klaus Nürnberger, who has recently published his two books on Dogmatics. The aim of the article is to stimulate further reflection on this fundamental article of the Christian faith.

Intradisciplinary and/or interdisciplinary implications: This article investigates the manifold interpretations that were given to the resurrection of Jesus Christ. This topic is widely discussed in Dogmatics and New Testament Theology as well as Practical Theology, especially Homiletics, where it has a huge effect on how the gospel is preached and how the essence of the gospel is defined. Since the Aufklärung of the 18th century, with its rationalism and positivism, the discussion built up momentum and the message of the resurrection was put into question from the side of science and scientism. This implied that the author had to discuss the relation between faith and science, trying to find an answer.
\end{abstract}

\section{Introduction}

The resurrection of Jesus Christ is a much discussed subject. Especially in an era where modernism (rationalism and positivism) and postmodernism determine the scientific debate, there is no place for metaphysics and mythology. Can a body be resurrected or be raised (again) from the dead? It is contrary to every human experience. And yet, this is not (just) a modern question. Even 2000 years ago during the times of Christ, there were Jews (Sadducees) who rejected this option wholeheartedly (Ac 23:8). Also Greek philosophers, like Plato, Epicurus and Stoa, rejected this idea.

The reality of the existence of a person like Jesus Christ, as well as the reality of his crucifixion, can easily be substantiated, but the resurrection of a person - after 3 days - seems to belong to the sphere of fiction. And yet, Christians continue to believe that Christ was raised from the dead and is alive as living Lord. What do they mean by that? Do they really believe that he was resurrected or should this point of view be defined metaphorically?

Should they view Jesus only as a pure human being without any divine characteristics? This 'humanistic' approach, that is propagated by the South African Old Testament scholar Sakkie Spangenberg, views him as nothing more than a Jewish prophet and wisdom teacher (Spangenberg 2009:362-367). His cross has no special liberating meaning and his resurrection, which could never have happened in any real sense of the word, is referred to the world of fiction and is therefore meaningless. This conclusion is derived from the fact that the Bible is an ordinary book like any other book, without any special authority or meaning, and totally overridden by the results of science and modernity (Spangenberg 2009:359-365). ${ }^{1}$

Spangenberg here follows the approach of the Jesus Seminar and the American theologian John Dominic Crossan (1991) who rejects the cross as an act of salvation as well as the reality and meaning of the resurrection. ${ }^{2}$

1.After a careful analysis of the views of the "New Reformers', Durand (2005:107) concludes that here we have to do with 'an alternative faith'.

2.See in this regard the profound criticism of Wright (1999:28-82) and Witherington III (1997:42-57) 
The opposite option is to understand the resurrection of Christ in a hyper-realistic way, as was the case with Lazarus, whose body was resuscitated after 4 days but who eventually died again. Scripture references that indicate this option are the following: Jesus asked his disciples for fish which he ate in their presence (Lk 27:42; see Jn 21:13). He also asked Thomas to put his hand in his side (Jn 20:27; see also Mt 28:9; Jn 20:17). The problem with this approach is that it uses a fundamentalist concept of Scripture interpretation and also ignores other accounts of the resurrected Christ. The fact that Christ could pass through closed doors (Jn 20:26) questions this option. The option of resuscitation leaves us with more questions than answers.

I now turn to the discussion of some of the different theological approaches to the resurrection of Christ that have developed over a period of time.

\section{Classic realistic interpretation: Pneumatic realism (resurrection [rising])}

I start with the classic understanding that most Christian churches and theologians developed from the very beginning of the so-called Christ-event. ${ }^{3}$ It means that Christ was resurrected or raised (by God) in a realistic way, such that he appeared afterwards to women, the apostles and other people. Yet he could move through closed doors (Jn 20:26) and disappear instantly (Lk 27:31). There are many biblical references applied in this regard.

With this approach, the resurrection of Christ is not understood in the same way as the resuscitation of Lazarus, who died again. Christ went triumphantly through death and appeared after his resurrection in a transformed way as Victor and living Lord.

To understand something of the new state of Christ, the information which Paul used in 1 Corinthians 15 should be applied. He refers here to Christ as the first (aparche) to be raised from death (1 Cor 15:20). Paul also refers to the bodily resurrection of believers and then distinguishes between what he calls a 'physical body' (soma psuchikon), which is buried, and a 'spiritual body' (soma pneumatikon), which is raised (1 Cor 15:44). With the latter description, Paul means a body (soma) which is totally occupied, possessed and transformed by the Spirit of God. It is important to note that he refers to a soma pneumatikon. With this he gives us a hint to understand the bodily resurrection of Christ: it is a soma totally possessed and transformed by the Spirit of God (see $1 \mathrm{Pt}$ 3:18).

This approach is followed by some of the most prominent theologians in the history of the church. ${ }^{4}$ It is evident that their hermeneutical presuppositions and exegetical interpretation of the Scripture play a decisive role in this regard.

\section{See in this regard the many confessions of the Christian churches worldwide.}

4.I follow here the advice of Noordmans (1979:184), who views the route followed by Augustine and Calvin as the safest.
The church-father Augustine opposed the Gnosticism of his time by emphasising the resurrection from the dead as a pivotal theme in theology. He argued that the bodily resurrection of believers rests on the resurrection of Jesus Christ (Augustinus 1983:10.29). The 'spiritual body' suggests imperishability (Augustinus 1983:20.21), yes, a body transformed to perfection (Augustinus 1983:22.1921). The church-father also argues that no Christian should have any doubt about the resurrection of the body (St Augustine 1987:2.84), which will be a spiritual body (1987:2.91). He (see Augustinus 1996:147 [Sermon 242A.2]) also refers in a sermon to the beginning of a human being: two small cells meet, connect and grow to become a full human being!

The church-reformer Calvin continued this line of thought. He closely relates the resurrection of Christ with the work of Christ: In the death and resurrection of Christ, we find a summary of our perfect salvation (Calvijn 1956, 2.16.5). He agrees that the resurrection of a (human) body is a 'difficult subject' (Calvijn 1956, 3.25.3), but he accepts the biblical teaching that the resurrection of the body will really take place (Calvijn 1956, 3.25.7).

It is interesting to note that Calvin ${ }^{5}$ views the third characteristic of the Christian life as meditation of the future life (meditatio future vitae). But if there is no future life, this kind of meditation during this life becomes meaningless. If there is no 'life beyond death', then a person's whole life is absorbed by the present life. There is nothing else to hope for.

The eminent Dutch theologian Bavinck agrees with Augustine and Calvin. He views the resurrection of Christ as an impressive part of the faith of the church. Without it the church would not have existed (Bavinck 1929:430). He also closely related this event with work of Christ, namely reconciliation. He emphasised the physical resurrection because it reveals a total victory of Christ over death. It was for Christ the entrance to an entirely new state of life, the beginning of an ever progressive exaltation (Bavinck 1978:367-372; Berkhof 1990:305; Berkhof in De Jonge (ed.) 1989:51-62; Berkouwer 1953:196-218; Ridderbos 1966:600617; Van de Beek 1998:163; Van Genderen \& Velema 1992:446455, 486-490, 779-782; Wentsel 1991:232-285).

This classical approach applies not only for Protestants, as mentioned above, but also for Roman Catholic (see Neuner \& Dupuis 1983:650:36, 37) as well as Eastern Orthodox theologians (see Alfeyev 2008:110-112).

\section{Main arguments}

One may ask: What are the main arguments for this classic pneumatic realism interpretation? I am going to select the most important ones. These are as follow:

5.See Calvijn 1956, 2.1.3; 2.10.1,3, 19,$22 ; 2.15,3 ; 3.7,3 ; 3.9 .1,4,5 ; 3.10 .4 ; 3.17 .15$ 3.18.1; $4.16 .3 ; 4.17 .1,2,4,8,17,32$. 
- There is a consensus among many prolific New Testament scholars ${ }^{6}$ that the first confession of the early Christians was: 'The Lord is risen indeed!' (Lk 24:34). This constitutes the climax of God's act of redemption.

- A very important consideration of the fact of the resurrection is the following: In the book of Acts, where we have examples of the first mission sermons, there is no reference in the first nineteen chapters to the crucifixion of Christ as a saving and life-giving fact in the speeches and sermons of the evangelists and apostles. 'The resurrection of Christ formed the main feature of the mission sermons of the early Christians' (Van der Watt \& Joubert 2010:113 in Van der Watt (ed.) 2010). The hallmark of the apostle who should replace Judas who had betrayed Christ was that he should be a witness of the resurrection of Christ (Ac 1:21-22). The emphasis in the first chapters of Acts is on the resurrection of Christ as the culmination of God's redemptive act to mankind. Only from Chapter 20 onwards does the cross of Christ appear in the same manner (see König 2014:452-454; see also 89-94, 107-109, 118, 126-135).

- Another significant indication relates to the fact that the message of the risen Christ was preached in a Hellenistic context in which the resurrection of a person was severely questioned (see Van den Brink \& Van der Kooi 2013:399, 396-403). The message of Paul brought him into direct conflict with the idealism of Plato and the materialism of Epicurus and Stoa (Ac 17). The Greek philosophers listened attentively to the message of Paul in Athens, but the moment he referred to the fact that God had raised 'that man' (Christ) from the dead, some of them made fun of Paul (Ac 17:31-32). It seems untenable to accept the gospel message of Paul, on the one hand, but to reject the confession of the resurrection of Christ, on the other: 'If it is for this life only that Christ has given us hope, we of all men are most to be pitied' (1 Cor 15:19)(NEB).

- It seems that already in the New Testament, a purely 'spiritual' (and gnostic) interpretation of the resurrection is mentioned but rejected (see 2 Tm 2:17, Hymenaeus and Philetus).

- This truth is illustrated by the fact that Paul could summarise the gospel while only referring to the resurrection (which he also did with the cross, 1 Cor 2:2): 'If you confess that Jesus is Lord and believe that God raised him from death, you will be saved' (Rm 10:9). Or: 'Remember Jesus Christ, raised from the dead, descended from David. This is my gospel ...' (2 Tm 2:8). See also 1 Corinthians 15:4 and 1 Peter 1:3. Salvation, we know, is always related to 'salvation of $\sin ^{\prime}$ in the New Testament (1 Cor 15:3; Gl 1:4).

- It is significant that one of the oldest books in the New Testament refers explicitly to the resurrection of Christ (1 Th 1:9-10; 4:13-18).

- All four Gospels, including the one by a medical doctor (Luke), explicitly refer to the resurrection, although with variations. Even Paul tells us that he met the risen Christ.
- Paul reflects on the raising of the Lord Jesus as a demonstration of the power of the God of creation (Rm 8:11; 1 Cor 5:14). Would it be impossible for God who created the universe ex nihilo to raise somebody from the dead?

- All four gospel writers, even Paul, mention the appearance of the risen Christ to living persons.

- In the whole of the New Testament, the risen Christ is described as living Lord and not as a dead person to whom believers must thankfully relate. Would the early Christians have been willing to die for a dead person who had given them only a wonderful example of a good life? To what must the fast growth of Christianity during the early centuries be attributed? In other words, is there any difference between a Christian's relation to Jesus Christ, on the one hand, and to Mr Nelson Mandela, on the other, both 'freedom fighters', and if so, how should we formulate the difference? ${ }^{7}$

- If Jesus was not resurrected, what meaningful interpretation should be given to the empty tomb? (see Berkouwer 1953:197-201).

- The transition of the Sabbath (seventh day) as day of worship to the Sunday (first day) as 'Day of the Lord' which took place in the early church can be fully attributed to the fact that Christ was raised from the dead on the Sunday (first day) morning.

It was these kind of considerations that led theologians to the following conclusions:

It is for sure the case that, also in a complete historical sense, there would have been no gospel, not a single message, no letter in the New Testament, no faith, no church, no worship service, no prayer in Christendom up to now without the message of the resurrection of Christ. (Bornkamm 1974:194-195)

Without the central salvific fact of the resurrection of Christ, there would never have been a New Testament and the religion that is called Christianity would never have existed. (Durand 1993:3)

The resurrection of Jesus is one of the central themes of the Christian faith. The resurrection, together with the cross of Jesus it forms the core of the early Christian speaking about Jesus. (Van de Beek 1998:163) (see also Van de Beek 2014:32-33, $44,144)$.

To this, we may add three other considerations:

- How can Western theologians communicate in a sensible way with Eastern Orthodox theologians, who did not experience the Aufklärung with its rationalism and for whom the resurrection of Christ (and Easter) is an essential part of the gospel message?

- African ever really experienced the full weight of Aufklärung with its rationalism and positivism. If we preach the cross of Christ to them as a real event, of course with a liberating meaning, how would they ever understand the full message if we tell them that the

7.Nürnberger $(2016,11: 218)$ asks the same question - to his readers - with reference to Mother Teresa and Mahatma Gandhi. 
resurrection of Christ never really happened but should be understood only in a metaphorical or symbolic way? It would be untenable to preach a sophisticated or metaphoric gospel message to (post-)modern Westerners and an elementary or realistic message to pre-modern Africans (see Nürnberger 2007).

- It is significant that prominent (natural) scientists who were atheists but later became Christians have no problem accepting the bodily resurrection of Jesus Christ. I refer here to one of the world's most prominent scientists, namely Francis Collins (see Chesterton 2006; Collins 2007:181-187; McGrath 2005). One would expect that a scientist, steeped in rationalism and positivism, would have insurmountable problems with the resurrection of Christ, but this did not happen. They were persuaded by the Holy Spirit to accept this message of faith (see McGrath 2005:181-187).

One may argue that we do not interpret every article of the Apostolicum in a realistic way, such as Christ's descent into hell ${ }^{8}$ - although the Roman Catholic Church accepts the latter in real terms. However, this article (of a late date) has no Scriptural basis and was understood for the first 1000 years in a metaphorical manner. ${ }^{9}$ As opposed to this, the message of the resurrection of Christ forms an essential part of the New Testament preaching and the gospel message as well as the church's confession right from the beginning.

Licona concludes his great study with the following words: 'I judged that the resurrection hypothesis is by far the best explanation of the historical bedrock' (Licona 2010:619). He also refers to the Jewish scholar Pinchas Lapide who commented that he could not understand the varying attempts of modernist theologians to interpret the resurrection in a metaphorical sense and to dehistoricise the message of all four evangelists (Licona 2010:545-546; see also Wessels 2006:253).

\section{Metaphoric-realistic interpretation: Metaphoric realism}

This interpretation has been developed by the South African theologian Jaap Durand in close relationship with Greshake. ${ }^{10}$ He first clarifies his hermeneutical approach as metaphorical, although I am convinced that he should have added the idea of realism, for he does not end with nothingness but with the kingdom of God, with living creatures living in creative relations with the living God and Christ (Durand 2010:131). Durand (1993:8) argues that 'there is a broad consensus that the Christian faith stands and falls with the historicity of its claims that Jesus lived, died on the cross and arose from the

8.See Nürnberger 2016a: 181 (heli), 182, 239 (right hand).

9.See Heidelberg Catechism 16.44

10.Greshake presented the resurrection as an event that takes place for individuals already at the moment of death, not at the last day; those who die move on at once from time to eternity, to the presence of the last day, to the return of Christ, to the resurrection and the judgement. See Pannenberg's (1998:578-579) criticism on Greshake: 'We can no more detach individual consummation from the question of universal consummation and vice versa'. dead'. However, the New Testament Easter testimonies as stated by Durand (1993) are as follow:

... are not meant to be testimonies to the resurrection as event, but testimonies to the risen One as person

... it is neither a miracle, breaking the laws of nature nor a supernatural intervention that can be located and dated in space and time, what happened transcends the limits of history. (p. 9)

The resurrection is not a historical event in the usual sense of the word.

The identity of Christ and the Spirit is central to the metaphor under discussion as well as to Paul's preaching of the resurrected Lord in general. It must be clear (Durand 1993) that:

the Pauline metaphor of 'Christ (the Spirit) in us' is hermeneutically the most suitable point of departure for a theological approach to the resurrection of Christ. There is an analogical correlation between what the text tells me and my own selfunderstanding because I recognize the claim of the text. (pp. 12-13)

The Pauline metaphor of the indwelling of the risen Christ in us should be taken as the starting point for a theological interpretation of the resurrection of Christ. Through the indwelling of the risen Christ as the life-giving Spirit in me, the past of the cross and the future of my own resurrection become a present reality. As stated by Durand (1993):

The resurrection of Christ is the salvific event by which God irrevocably accepts and fills the fallen creation as his own reality. He unites the human race to himself through the risen and glorified Christ in such a way that he in his Godhead can never again be thought of as being without them. In so doing he retrospectively affirms the incarnation and the cross and in anticipation he guarantees the future consummation. (p. 14)

On the question of what happens with believers after death, Durand (1993) argues that we should distance ourselves from the Greek idea of two substances, body and soul, which has dominated Christian thought for many centuries. He argues that:

through the Spirit of the risen Christ the resurrection becomes part of my own life. I am irrevocably united to God, partaking in his eternity. This is the beginning of the resurrection life in me, in fact the beginning of my own resurrection, which comes to completion at the moment of my death. (p. 17)

When Paul refers to 'body' in 1 Corinthians 15, we should interpret it as a metaphor which tells us 'that the same person at the moment of death will live on in a different mode of existence, partaking in the life-giving Spirit of the resurrected Christ' (Durand 1993:18). 'The moment I close my eyes in death, I open them in, the vision Dei of my resurrection' (Durand 1993:19, 2010:124). Death means a transition into a new way of existence (Durand 2010:116, 117).

Durand mentions that these views evade the many questions raised by the idea of an intermediate state and although many formulations tend to a one-sided metaphorical approach, he is of the opinion that he does not radically 
depart from the traditional thought (Durand 1993:20; see also Durand 2014:191). It is clear that he does not deny the idea of 'eternal life' for believers (Durand 2010:116). But through the indwelling of the Spirit, they participate in eternity already, now.

This same approach is also followed by the Dutch theologian B. Telder (1960:151-175) with his book, Dying ... and then?, who developed this theme in the same direction. It seems that Moltmann (1996:103) thinks in the same direction: the individual resurrection from the dead takes place with, and at, death.

\section{Metaphorical interpretation: Demythologisation}

The Aufklärung of the 18th century with its rationalism followed by positivism - brought the classic understanding of the Bible under severe pressure. It is assumed that the new world view must have an important impact on the way we interpret the Bible. The famous New Testament scholar, Rudolf Bultmann, argued that it is impossible to use electric light and the radio as well as modern and clinic remedies for ill persons and, at the same time, to believe in the New Testament world of spirits and miracles (Bultmann 1969:24). Modern persons do no longer think in terms of a natural and supernatural world. To overcome this problem, Bultmann linked up with the existentialist philosophy of Heidegger and developed his well-known method of demythologisation. He argues that the resurrection of Christ forms part of the mythological world view. 'Next to the historical fact of the cross', he says, 'stands the elevation, which is no historical event' (Bultmann 1968:47-48, 1969:60, 69). The resurrection is not something that happened in the garden of Joseph, but in the subjective experience of the disciples of Jesus. Jesus arises in the kerugma (as the Christ). ${ }^{11}$

Bultmann uses the concepts 'authentic' and 'inauthentic' existence, which he borrows from Heidegger, to clarify his approach. A person should cross from an inauthentic existence to an authentic existence - that is from an existence of alienation, anxiety, agony, guilt and finiteness to an existence of liberation and freedom. Such an existence can only be produced by the gospel of the cross and through faith. Salvation means that a person rejects all hope that he or she can arrive at an authentic existence in his or her own strength, because it can only be received by the grace of God (Bultmann 1967:58, 1969:41, 51). Thus, salvation cannot objectively be mediated by the historic Jesus, but subjectively by the proclaimed Christ (Bultmann 1968:305-306).

Another author who seems to appreciate the views of Bultmann is the eminent Roman Catholic theologian Hans Küng (see 1967:75-82, 1993:103-112), although his views sometimes lack some clarity. ${ }^{12}$ On the one hand, he could

11.See McGrath (1994:157-173) and Jee (2002:15-19) on Bultmann. See also Barth (1953).

12.See the remark of Karl Barth on Küng's book The Church: Barth highly appreciates the book, but experiences Küng's pages on the Bultmann school as rather 'slippery' (see Dekker \& Puchinger 1969:82). argue that the resurrection of Jesus by God to eternal life 'is not a historical event'. It has to be said quite plainly 'that God does not need the bodily remnants of the earthly existence of Jesus for the identity of the person to be preserved'. In this way, Küng emphasises the discontinuity between the crucified Jesus and the resurrected Christ. On the other hand, he accepts a certain kind of continuity and uses the metaphor of a butterfly and a caterpillar to portray this idea. This metaphor clearly illustrates the continuity and the discontinuity. Jesus died 'into that ineffable and incomprehensible last and first reality', who is God. For a believer, death 'is a transition to God' (Küng 1993:11-112).

The views of Bultmann not only influenced the debate in Germany and Europe but also captured the attention of a wide range of South African theologians. There are theologians of the Hervormde Kerk (NHKA) that have great appreciation for the stance taken by Bultmann, such as Pelser (1997:455-475), Van Aarde (2000:549-571, 2001) and Malan (2000:237-258, 2008). ${ }^{13}$ Flip Schutte (see Jackson 2008:17) quitted the Hervormde Kerk because his conscience did not allow him to continue to be a minister in this church; he found it impossible to continue preaching during Christmas and Easter 'in honesty' while rejecting the idea of metaphysics (see also Schutte 2008).

This debate is also carried on in the Dutch Reformed Church (DRC) and it is difficult to say whether it has been brought to full clarity (see Gaum 2004). There are those who support the classic interpretation of the resurrection, ${ }^{14}$ while others, such as Müller $(2006,2011)$, are more hesitant or uncertain..$^{15}$ Also the theologian-philosopher Anton van Niekerk questions the idea of 'life beyond death' (2005:218-239, 2017:90-120) and ends with the slogan: 'I don't know' (2017:118).

\section{Metaphorical interpretation: Elevation}

I now turn in more detail to the views of the South African theologian Klaus Nürnberger. I do so because he is one of the prominent theologians in South Africa, well-informed, a man of intelligent argumentation and always thought-provoking. His approach to contextualise the biblical message for modern persons and to take careful note of the contribution of science in this regard is extremely important. It will become clear, however, that Nürnberger questions the traditional interpretation of the resurrection and closely relates to the approach of Bultmann.

13.See in this regard the critical debate between Pelser (2001a:5, 8, 2001b:5 2001c:15) and Van Wyk (jr.) $(2002: 5,8)$.

14.See Heyns (1978:265-266, 408-410), König (2001:99-105, 2009:168-192, 236-274, 2014:89-94, 107-109, 118-120, 126-131, 2017:137-140, 212-231), Van der Watt and Joubert (in Van der Watt 2010:112-121); Vos (2015:183-186), Wessels (2006) and Joubert (2009:160).

15.See the critical reaction of König (2009:236-253) on the views of Müller. See further the sensational book of Mulder (2011), with very little reaction on his arguments. See in this regact al on arguments. See in this regard also Gert Steyn on the resurrection and the Synoptic (2011:284-308) and Kobus Kok on the resurecton and Paul (2011:309-322), (2011:284-308) and Kobus Kok on the resurrection and Paul (2011:309-322), although the last is not always clear on the matter, all of them in C. Vos and D. Human (eds.) (2011). See also Du Plessis (2005). 
In 1975, Nürnberger was the first South African to publish a full study on systematic theology (in Afrikaans), called Sistematiese Teologie. After 40 years of study, lecturing and writing, his seasoned study on the same topic has now been published, this time in two volumes which cover more than 1000 pages. It is an intriguing exercise to see how the views of the author developed and changed through the decades of theological reflection. On the last pages of his latest book, the author has done us a favour by setting out and explaining the way he travelled as theologian and how he finally reached his mature considerations. He consistently followed the experiential-realist approach, continuing on the same line as critical exponents of the Lutheran tradition in Central Europe during the 20th century. He also followed an unambiguous historical-critical reading of the Bible and related and linked the message of the Bible with other disciplines such as natural sciences.

It is imperative to understand his basic motivation, namely to take the historical nature of the biblical Scriptures seriously and to make the ancient message plausible to our contemporaries. For this reason, he has adopted the approach of experiential realism - according to 1 Corinthians 9:19-23. ${ }^{16}$

The author assists us by giving us a summary of his message in a nutshell at the beginning of his book, which I will now summarise to clarify his way of thinking because it is important for his understanding of the resurrection.

He starts by saying that theology is the quest of believers for an understanding of what they believe, which means that faith comes first and then follows theology. Religious faith is the intuition that reality is derived from a transcendent Source and headed towards a transcendent Destiny, while theology seeks to clarify this intuition. And then follows what may be called the essence of the whole argument (Nürnberger 2016b):

Christian faith responds to the 'Word of God', that is, the message of God's creative power, God's benevolent intentionality and God's comprehensive vision for the world as manifest in Christ. (p. xi)

As far as the biblical material is concerned, the author focuses on Genesis and Deuteronomy, Paul and his school, the Synoptic Gospels and the writings of John.

The Word of God is not described as a static entity but as a Word that emerged and evolved in human history in the form of a living tradition. During biblical times, it functioned as God's redemptive response to the specific human predicament and world views, culminating in the 'Christevent'. The Word of God is proclaimed by each successive generation of believers on the basis of the biblical tradition. Whenever we accept this message in faith, it manifests its power by calling us into God's presence, accepting us into God's fellowship and transforming us into God's vision for the world.

16.See Nürnberger $2016 \mathrm{~b}$, part 1, especially no 5 . See also Nürnberger $(2004,2009)$.
In the face of all contradictory indications, we believe this reality to be the ever new outcome of God's creative power and benevolent intentionality. Faith is therefore always a tenacious struggle to remain open for the reassurance of God's benevolence against the vagaries of experienced reality. This faith is always challenged in a never-ending process. After two millennia, we have to figure out which is the best way of interpreting the ever-changing message of God.

The author views it as the task of theology to provide a reasonably comprehensive and consistent overview of the Christian faith as a whole.

How does Nürnberger view the resurrection of Jesus Christ?

It is interesting that he prefers to use the concept 'elevation' instead of 'resurrection' to describe what happened to Christ after his crucifixion and burial. For Nürnberger, the cross of Christ is 'the core of the New Testament message' (Nürnberger 2016a:508). 'God's suffering, self-giving love, as manifest in the Christ-event, is "the core of the Christian faith"' (Nürnberger 2016a:508). We should, however, distinguish between Jesus of Nazareth as a real human being ... on the one hand, and Christ as the prototype of the true or authentic human being, on the other (Nürnberger 2016a:176).

The idea of a bodily resurrection of Christ is untenable. Science excludes the message of a real resurrection of Christ. 'The risen Christ is the prototype of a sacrificial life. He lived and died on our behalf, and we are allowed to participate in his life and death on behalf of others' (Nürnberger 2016a:230).

'Resurrection is not a historical fact' (Nürnberger 2016a:242). The risen Christ is 'present for us, among us, and in us as a spiritual being' (Nürnberger 2016a:237). 'The "risen Christ" stands for a new humanity that lives in fellowship with God, sharing God's creative and comprehensive vision and participating in "his" redemptive action' (Nürnberger 2016a:238).

In another study, Nürnberger (2010b:170) tends in the same direction but without a final conclusion. He argues that when Christians are confronted by death, 'they are reassured of being re-integrated into the greater life of the Source and Destiny of life, whatever that may mean'.

The question now arises whether there is any difference between the views of Nürnberger and that of Bultmann. Although he sometimes criticises Bultmann (Nürnberger 2016a:550), in an e-mail (K. Nürnberger, pers. comm., 28 Sep. 2017) to me, he affirms the influence of Bultmann on him:

'Bultmann indeed influenced me because through him I understood, for the first time, that we must distinguish between the intended meaning of the message and its packaging in ancient world-views that are no longer immediately plausible for us today.'

With this view, Nürnberger radically deviates from the views which he defended in his systematic theology of 1975 where he rejected the stance of Bultmann (Nürnberger 1975:356-357). 
As is the case with Bultmann's, Nürnberger's approach raises some serious questions of which I am going to mention some.

- The essence of the gospel: the cross and/or the resurrection? If we argue that the crucifixion of Christ is a historical fact while the elevation or resurrection is not, how should we define the gospel message which the Scripture describes in both terms (1 Cor 2:2 and Rm 9:10)? Should we accept the historicity or reality of the cross while giving a metaphorical or symbolic interpretation of the resurrection? Is the acceptance of the (transformed) reality of the risen Christ a reification of a metaphor which Nürnberger rejects - or is it a confession of faith in the risen and living Christ?

- The difference between the church and Christ. A second question is whether Nürnberger regards the risen Christ as existing and living outside of the enactment of a new life in Christ by the body of Christ or is the risen Christ absorbed, as it were, by the body of Christ (i.e. the church)? (Wethmar 2018:5). This question relates to the extra Calvinisticum. ${ }^{17}$

- The relation between science and theology. For Nürnberger, science plays a very important role in the interpretation of the Bible. 'Science has provided us with a deeper insight into reality than could have been available to the authors of the Bible' (Nürnberger 2016a:481). Thus 'modern scientific insight excludes a literal quasi-biological interpretation [of resurrection from the dead]' (Nürnberger 2016a:511). ${ }^{18}$ He rejects the approach of fideism (no science, only faith), as well as scientism (only science, no faith), or in the case of dualism, where faith and science operate as two totally separate models with no relation to one another. Instead he has chosen for a complementary model where there is a correlation between science and faith. "Science is about explanation; faith is about meaning. Science is about prediction; faith is about vision. Science is about immanence; faith is about transcendence. Science is about knowledge; faith is about commitment." (Nürnberger 2011:17). ${ }^{19}$ Science needs 'best faith' to be responsible while science needs 'best faith' to be credible.

- It is clear that Nürnberger differentiates between faith and science and also interrelates them. The question which arises is how can we actively avoid that science dominates and overrules faith to such an extent that faith becomes superfluous? How can we avoid scientism? If science tells us that the universe, which started with a Big Bang, will one day collapse in a Big Crunch which will be the end of the universe, ${ }^{20}$ should we accept that as the purpose of God's benevolent intentionality and comprehensive vision for the world? Is it meaningful to

17.See here the classic Reformed Form for the Lord's Supper where participants are reminded not to cling with their hearts unto the bread and wine but lift them up on high in heaven, where Christ Jesus is, at the right hand of the heavenly Father.

18.See inter alia Nürnberger (2016a:198, 227, 232). See also Nürnberger (2010a).

19.See Collins (2007:211): 'The God of the bible is also the God of the genome. He can be worshiped in the cathedral and in the laboratory'.

20.It must be acknowledged that scientists disagree on this matter: While Hawking $(1989: 36,183)$ is of the opinion that a Big Crunch may take place, Dawkins $(2007: 174)$ thinks that it may not take place and that the universe will expand ad infinitum. believe in such a God? If entropy speaks the last word, will eschatology not disappear over the abyss?

The following question becomes unavoidable: How can we hold on to the basic gospel message of the cross and the resurrection on the one hand while accepting the effect of the modern world view and science on the meaning of that gospel and thus dehistoricising and demythologising the resurrection on the other hand? In other words, how should we use the results of science in such a way that it does not change the essence of the gospel message, thus avoiding scientism? ${ }^{21}$

- The relation between science and eschatology. Another question which must be answered is: what about eschatology? In 1994, Nürnberger (1994:149) wrote that 'the process of entropy will be superseded by a new creation', but it seems that he has changed his mind. ${ }^{22} \mathrm{He}$ now says that eternal life, apocalyptic eschatology and expectations are futile. Realistic eschatology is not likely to materialise (Nürnberger 2016a:481, 492). 'It is important to realise that the assumption of a new life after death, if taken literally, is just as improbable as the assumption of a new creation without entropy after the existing world has reached its catastrophic end' (Nürnberger 2016a:485). 'It is clear therefore, that the concept of "eternal" life in the New Testament does not refer to Platonic timelessness, or to endless continuation of biological life, but to a life in unobstructed fellowship with God lived here and now ... resurrection and eternal life were essentially about authenticity rather than longevity' (Nürnberger 2016a:497). 'There will come a time when we will cease to exist. But the consequences of our lives will continue at least up to the end of life on planet earth' (Nürnberger 2016a:506). This approach invokes the question whether the classic eschatological hope for a new creation - a new heaven and a new earth - disappears over the horizon?

- What about a theology of hope? In 1964, 19 years after the Second World War, Jürgen Moltmann wrote his famous book on a Theology of hope to revive a mode of optimism and hope in Western Europe after 60 million people were killed. The question with which we are confronted now is that experts predict a catastrophe of cosmic proportions by the year 2050 because of earth pollution and we now need another theology of hope. Does the theology of Nürnberger provide such a hope? Will there be any future life, any new creation?

Christian faith hopes for the total renewal of the universe as God's final plan with his creation. ${ }^{23}$ While scientism only takes into account the results of science and futurology, Christian theology also takes into consideration the Creator and eschatology and a cosmic

21.On the relationship between faith and science, see also Van Huyssteen (2006).

22.In an article on the new heaven and the new earth, Nürnberger writes as follows: Finally, there will be no death in God's eschatological future. Or expressed in cosmic terms, the process of entropy will be superseded by a new creation. That is the hardest nut to crack for a modern scientifically informed consciousness. (Nürnberger 1994:149)

23.Wilkinson (2010:157) views the resurrection from the dead as the secret that a new creation is on the way. 
destiny 'beyond the collapse or decay' (Polkinghorne 1996:53, 54). A Christian also hopes that 'the pattern that is me will be remembered and re-embodied by God in his eschatological act of resurrection' (Polkinghorne 1996:54). ${ }^{24}$ While science speaks of a possible Big Crunch and a total destruction of the universe, Christian theology accepts in faith 'a transforming new act by the faithful Creator' (Polkinghorne 1996:83).

\section{Nürnberger's reaction}

In a personal e-mail conversation (K. Nürnberger, pers. comm., 11 Jun. 2017) with Nürnberger, he assured me of the following, which I quote:

For KN science does not have the last word, because (a) in terms of the current worldview it is always provisional and (b) in terms of the redemptive intentionality of God as it manifested itself in Christ it has nothing to say whatsoever.

Christ is alive for KN. He has written a whole chapter on the elevation of Christ. He used the word 'elevation' of Christ rather than 'resurrection' because he thinks it reflects the reality of Christ for us today better. It is the bodily crucified Jesus who has become the 'Lord' for us and who manifests himself in our bodies.

My approach of experiential realism is based on 1 Corinthians 9:19-23 - becoming all things to all people - thus driven by a missionary agenda.

\section{Conclusion}

We have travelled a long way in search of an answer on the question how we should interpret the resurrection of Jesus Christ. It is a question which involves the interpretation of Scripture, the relation between faith and science, Christology and in the end eschatology. We had a look - inter alia - at the classical pneumatic-realistic way of understanding the resurrection as well as the metaphorical or mythological way, each with its own substantiations.

It seems that this whole debate boils down to one simple question: what is the essence of the gospel: the cross and resurrection of Christ, as pneumatic realities and as triumph over sin and death, or only the cross as reality, with the resurrection as (only) a metaphor for Christ as the prototype for the true and authentic human being?

\section{Acknowledgements Competing interests}

The author declares that he has no financial or personal relationships which may have inappropriately influenced him in writing this article.

\section{References}

Alfeyev, H., 2008, 'Eschatology', in M.B. Cunningham \& E. Theokritoff (eds.), Orthodox Christian theology, pp. 107-120, Cambridge University Press, Cambridge.

Augustine (St), 1987, The enchiridion on faith, hope and love, transl. H. Paolucci, Regnery Gateway, Washington, DC

24. See the following hesitant formulation of Nürnberger (2010b):

When faced with the prospect of eternal nothingness because the end of their lifetime is at hand, they [Christians] are reassured of being re-integrated into the greater life of the Source and Destiny of life, whatever that may mean. (p. 170)
Aurelius Augustinus, 1983, De stad van God, transl. G. Wijdeveld, Ambo, Baarn.

Aurelius Augustinus, 1996, Als licht in het hart. Preken voor het liturgisch jaar (sermones de tempore), transl. J. van Neer, M. Schrama, A. Tigchelaar \& P. Wammes, Ambo, Baarn.

Barth, K., 1953, Rudolf Bultmann: Ein Versuch, ihn zu verstehen, Zollikon, Zürich.

Bavinck, H., 1929, Gereformeerde Dogmatiek, Deel III, Kok, Kampen.

Bavinck, H., 1978, Our reasonble faith. A survey of Christian doctrine, transl. H. Zylstra, Baker Book House, Grand Rapids, MI.

Berkhof, H., 1990, Christelijk geloof: Een inleiding tot de geloofsleer, Callenbach, Nijkerk.

Berkouwer, G.C., 1953, Dogmatische Studiën. Het werk van Christus, Kok, Kampen.

Bornkamm, D.G., 1974, Jesus van Nasaret, transl. A.B. du Toit, Teologiese Seminarie van die Broederkerk in Suid-Afrika, Kaapstad.

Bultmann, R., 1967, Jezus en de mythe, Ten Have, Amsterdam.

Bultmann, R., 1968, Theologie des Neuen Testaments, Mohr (Paul Siebeck), Tübingen.

Bultmann, R., 1969, Geloof zonder mythe, Romen \& Zonen, Roermond.

Calvijn (Johannes), 1956, INSTITUTIE of Onderwijzing in de Christelijke Godsdienst Deel I-III, transl. A. Sizoo, Meinema, Delt.

Chesterton, G.K., 2006, Orthodoxy, Hendrickson, Peabody, MA. (Original 1908).

Collins, F., 2007, The language of God. A scientist presents evidence for belief, Pocket Books, London.

Crossan, J., 1991, The historical Jesus: The life of a Mediterranean Jewish peasant, Harper, San Francisco, CA

Dawkins, R., 2007, The God Delusion, Black Swan, London.

De Jonge, M. (ed.), 1989, Waarlijk opgestaan! Een discussie over de opstanding van Jezus Christus, Ten Have, Baarn.

Dekker, A. \& Puchinger, G., 1969, Die oude Barth zoals wij hem hoorden in colleges en gesprekken, Kok, Kampen.

Du Plessis, I., 2005, Jesus: Die keuse. Eerlike geloofsvrae oor die Jesus gesprek, Lux Verbi, Wellington.

Durand, J., 2005, Doodloopstrate van die geloof. 'n Perspektief op die Nuwe Hervorming, Rapid Access Publishers, Stellenbosch.

Durand, J., 2010, Dis is amper dag. 'n Besinning oor die najaar van die lewe... Christelike Uitgewers Maatskappy, Vereeniging.

Durand, J., 2014, Jaap Durand praat oor eenheid, versoening en geregtigheid, red. Danie du Toit, Bybelkor, Wellington.

Durand, J.J.F., 1993, 'Theology and resurrection - Metaphors and paradigms', Journal of Theology for Southern Africa 82, 3-20.

Gaum, F. (red.), 2004, 20 Gesprekke oor die opstanding van Jesus uit die dood, Ex Animo, Kaapstad.

Hawking, S., 1989, A brief history of time. From the Big Bang to black holes, Bantam Press, London.

Heyns, J.A., 1978, Dogmatiek, N.G. Kerkboekhandel, Pretoria.

Jackson, N., 2008, 'Wanneer die domino's val. Een ná die ander Christen-konsep val', Beeld, 21 November, p. 17.

Jee, M.-S., 2002, 'Yet and not yet? A dogmatical study in modern eschatology', M.Div, Dept. of Theology, University of Potchefstroom for Christian Higher Education.

Joubert, S., 2009, Jesus, 'n radikale sprong. Koninkryk, kerk en wêreld: Waar pas ek in?, Christelike Uitgewersmaatskappy, Vereeniging.

Kok, K., 2011, 'Opstanding by Paulus' in Cas Vos \& Dirk Human (eds.) 2011, Vaste Rost op wie ek bou, Lux Verbi, Kaapstad.

König, A., 2001, Die helfte is my nooit oor Jesus vertel nie. 'n Nuwe kyk op die een wat jou lewe verander het, Lux Verbi, Wellington.

König, A., 2009, Die Evangelie is op die Spel. Die verwarring oor die Bybel en oor Jesus se lewe, sterwe en opstanding. 'n Alternatief op liberalisme en fundamentalisme, Lux Verbi, Wellington.

König, A., 2014, Die Groot Geloofskommentaar, Christelike Uitgewersmaatskappy, Vereeniging.

König, A., 2017, Paulus. Die indringer-apostel wat die evangelie gered het, Christelike Uitgewers maatskappy, Vereeniging.

Küng, H., 1967, De Kerk, transl. H. Wagemans, Paul Brand, Hilversum.

Küng, H., 1993, Credo. The Apostles' creed explained for today, transl. J. Bowden, SCM Press, London.

Licona, M.R., 2010, The resurrection of Jesus. A new historiographical approach, InterVarsity Press, Downers Grove, IL.

Malan, G., 2008, Om die Bybel (beter) te verstaan, Sentik, Pretoria.

Malan, G.J., 2000, 'Analogiese taal by Bultmann in die lig van die kennissosiologie', Hervormde Teologiese Studies 56(1), 237-258.

McGrath, A., 2005, Bruggen bouwen. Over het effectief doorgeven van het christelijk geloof, Voorhoeve, Kampen.

McGrath, A.E., 1994, The making of modern German Christology 1750-1990, Zondervan, Grand Rapids, MI.

Moltmann, J., 1996, The coming of God. Christian eschatology, transl. M. Kohl, SCM Press, London. 
Mulder, F., 2011, Opgestaan. Studente se stryd om geloof by Tukkies in die jare 20012006, Opgestaan Publikasies, Cambridge.

Müller, J., 2006, Opstanding, Lux Verbi, Wellington.

Müller, J., 2011, Om te mag twyfel. 'n Gelowige se reis, Tafelberg, Kaapstad.

Neuner, J. \& Dupuis, J. (eds.), 1983, The Christian faith in the doctrinal documents of the Catholic Church, Collins, London.

Noordmans, O., 1979, Verzamelde Werken Deel II. Dogmatische Peilingen rondom Schriften, Belijdenis, Kok, Kampen.

Nürnberger, K., 1975, Sistematiese Teologie, Genadendalse Drukkery, Genadendal.

Nürnberger, K., 1994, 'Towards a New Heaven and a new earth', in J. de Gruchy \& C. Villa-Vicencio (eds.), Doing theology in context. South African perspectives, pp. 139-149, David Philip, Cape Town.

Nürnberger, K., 2004, Biblical theology in outline. The vitality of the word of God, Cluster, Pietermaritzburg.

Nürnberger, K., 2007, The living dead and the living God. Christ and the ancestors in a changing Africa, Cluster Publications, Pietermaritzburg.

Nürnberger, K., 2009, Die Bybel. Verantwoordelik lees is krities lees, Lux Verbi, Wellington.

Nürnberger, K., 2010a, 'Becoming a scientist to the scientists: Theses on the relation between natural science and Christian faith', Journal of Theology for Southern Africa 136, 92-112.

Nürnberger, K., 2010b, Richard's Dawkins' God delusion. A repentant refutation, Xlibris, London.

Nürnberger, K., 2011, Regaining sanity for the earth. Why science needs 'best faith' to be responsible. Why faith needs 'best science' to be credible, Xlibris, London.

Nürnberger, K., 2016a, Faith in Christ today: Invitation to systematic theology, Vol. I, Life in the presence of God, Cluster, Pietermaritzburg.

Nürnberger, K., 2016b, Invitation to Systematic Theology. Vol. II: Involved in God's project, Cluster, Pietermaritzburg.

Pannenberg, W., 1998, Systematic theology Vol. 3, transl. G.W. Bromiley, Eerdmans, Grand Rapids, MI.

Pelser, G.M.M., 1997, 'Rudolf Bultmann oor die opstanding van Jesus', Hervormde Teologiese Studies 53(3), 455-475. https://doi.org/10.4102/hts.v53i3.1655

Pelser, G.M.M., 2001a, 'In gesprek oor die opstanding van Jesus (2)', Die Hervormer, 15 September, pp. 5,8

Pelser, G.M.M., 2001b, 'Nogeens die opstanding van Jesus', Die Hervormer, 01 December, p. 5

Pelser, G.M.M., 2001c, 'Nogeens die opstanding van Jesus (2)', Die Hervormer, 15 December, p. 5.

Polkinghorne, J., 1996, Scientists as theologians. A comparison of the writings of lan Barbour, Athur Peacock and Jonh Polkinghorne, Society for Promoting Christian Knowledge, London.

Ridderbos, H., 1966, Paulus. Ontwerp van zijn Theologie, Kok, Kampen.
Schutte, F., 2008, Jesus' resurrection in Joseph's garden, Pretoria Book House, Pretoria. Spangenberg, S. (I.J.J.), 2009, Jesus van Nasaret, Griffel, Kaapstad.

Steyn, G., 2011, 'Opstanding in die sinoptiese Evangelies' in Cas Vos \& Dirk Human (eds.) 2011, Vaste Rots op wie ek bou, Lux Verbi, Kaapstad.

Telder, B., 1960, Sterven...en dan?, Kok, Kampen.

Van Aarde, A., 2000, 'Die relevansie van die historiese Jesus-ondersoek vir kerklike teologie', Hervormde Teologiese Studies 56(2 \& 3), 549-571.

Van Aarde, A., 2001, Fatherless in Galilee: Jesus as Child of God, Trinity, Harrisburg.

Van de Beek, A., 1998, Jezus Kurios. De Christologie als hart van de theologie, Kok, Kampen.

Van de Beek, A., 2014, Een lichtkring om het kruis. Scheppingsleer in christologisch perspectief, Meinema, Zoetermeer.

Van den Brink, G. \& Van der Kooi, C., 2013, Christelijke Dogmatiek. Een Inleiding, Boekencentrum, Zoetermeer.

Van der Merwe, D., 2011, 'Opstanding in die evangelie van Johannes' in Cas Vos \& Dirk Human (eds.) 2011, Vaste Rots op wie ek bou, Lux Verbi, Kaapstad.

Van der Watt, J. (red.), 2010, Wie sê julle is Ek?, Christelike Uitgewersmaatskappy, Vereeniging.

Van Genderen, J. \& Velema, W.H., 1992, Beknopte Gereformeerde Dogmatiek, Kok, Kampen.

Van Huyssteen, W., 2006, Alone in the world? Human uniqueness in science and theology. The Gilford lectures, Eerdmans, Grand Rapids, MI.

Van Niekerk, A.A., 2005, Geloofsondersekerhede. Besinning vir eietydse gelowiges, Lux Verbi, Wellington.

Van Niekerk, A.A., 2017, Die dood en die sin van die lewe, Tafelberg, Kaapstad.

Van Wyk, D.J.C., Jr., 2002, 'Die opstanding en die vraag na die historiese Jesus', Die Hervormer, 01 Maart, pp. 5, 8 .

Vos, C., 2015, Dáárom glo ek. 'n Uitnodiging tot 'n geloofsreis in 'n tyd van twyfel en verwarring, Bybel-Media, Wellington.

Vos, C. \& Human, D. (eds.), 2011, Vaste Rots op wie ek bou, Lux Verbi, Kaapstad.

Wentsel, B., 1991, God en mens verzoend: Incarnatie, verzoening, koninkrijk van God. Dogmatiek 3b, Kok, Kampen.

Wessels, F., 2006, Wie was Jesus regtig? Oor die historiese Jesus, Lux Verbi, Wellington.

Wethmar, K, 2018, Klaus Nürnberger's approach to ecclesiology in his 'Faith in Christ today', Presentation during a seminar held at the University of Pretoria, Pretoria, 29 January.

Wilkinson, D., 2010, Christian eschatology and the physical universe, T \& T Clark, London.

Witherington, B., III, 1997, The Jesus quest: The third search for the Jew of Nazareth, InterVarsity Press, Downers Grove, IL.

Wright, N.T., 1999, Jesus and the victory of God, Society for Promoting Christian Knowledge, London. 